\title{
EDTA Blood Cell Fraction
}

National Cancer Institute

\section{Source}

National Cancer Institute. EDTA Blood Cell Fraction. NCI Thesaurus. Code C158462.

The blood cells that are harvested from a cell collection tube containing EDTA. 